\title{
A Eleição Visível: A Rede Globo Descobre a Política em 2002*
}

\author{
Luis Felipe Miguel
}

S egunda-feira, 28 de outubro de 2002. Um retirante nordestino, pesindicalista, ocupa os estúdios do mais importante telejornal brasileiro. Durante 1h15min, ele senta-se ao lado do âncora, acompanha as notícias, responde a uma e outra pergunta - e até dá o "boa noite" final, no lugar do apresentador. Luiz Inácio Lula da Silva, naquele momento, já se fizera presente nos mais distantes lugares do país, como líder popular, chefe de seu partido, quatro vezes candidato à Presidência. Há pouco mais de 24 horas, tornara-se presidente eleito, com cerca de 51 milhões de votos. Ainda assim, causava estranhamento sua presença, marcada por inúmeras homenagens, em pleno Jornal Nacional da Rede Globo.

\footnotetext{
* A pesquisa contou com a colaboração de Sara Freire Simões de Andrade, aluna do curso de graduação em Ciência Política da UnB e bolsista do PIBIC/CNPq/UnB, responsável pelo acompanhamento do Jornal Nacional e pela classificação das reportagens, a quem agradeço também pelas sugestões ao texto. Uma versão inicial foi apresentada na mesa-redonda Mídia e Eleições Presidenciais no Brasil em 2002, no III Encontro (Inter)Nacional de Estudos de Comunicação e Política, Salvador, dezembro de 2002. Sou grato aos co-expositores e ao público pelas contribuições valiosas. Devo agradecer, ainda, a leitura atenta de Regina Dalcastagnè e as sugestões dos pareceristas anônimos de Dados.
}

DADOS - Revista de Ciências Sociais, Rio de Janeiro, Vol. 46, nº2, 2003, pp. 289 a 310. 
Um Rip Van Vinkle caboclo que tivesse dormido em 1989 e só acordasse treze anos depois dificilmente acreditaria em seus olhos. Na primeira eleição direta para a Presidência do Brasil após o final da ditadura, a Rede Globo alinhou-se de forma clara com os adversários de Lula e, com o material apresentado em telejornais e mesmo novelas, contribuiu para sua derrota. Em 2002, porém, o clima entre o líder do Partido dos Trabalhadores e a maior emissora de televisão do país não era apenas cordial, era festivo. Mas não seria preciso recuar tanto tempo. Mesmo quem assistisse ao Jornal Nacional de 28 de outubro tendo em mente as circunstâncias da eleição anterior, ocorrida em 1998, teria motivos para espanto. A presença do presidente eleito nos estúdios do telejornal foi a culminância da "maior cobertura eleitoral" da história, conforme a própria Globo não se cansou de anunciar. Quatro anos antes, pelo contrário, as eleições foram praticamente banidas do noticiário.

Essa nova "descoberta da política" pelo maior conglomerado brasileiro de comunicações - e, em sua esteira, pelo restante da mídia no país - foi, em si mesma, um dos fenômenos mais importantes do processo eleitoral de 2002. A vitória de um candidato de esquerda inaugura um período de possíveis mudanças no relacionamento entre as empresas de comunicação e o poder político no Brasil1. O "oba-oba" em torno do presidente eleito parece maior do que o ocorrido nas eleições anteriores, mas não se deve a supostas características messiânicas de Lula, como quiseram alguns, nem é inédito. Em 1985, a vitória de Tancredo Neves no Colégio Eleitoral foi cercada de um clima similar, em grande medida alimentado pela televisão (e que se prolongaria até sua morte, pouco mais de um mês depois da data da posse). Não por acaso, são dois momentos de grande expectativa por mudanças: antes, o retorno dos civis ao poder; agora, o triunfo das esquerdas. Sob o primeiro governo civil, a Rede Globo viveu o ápice de sua influência política; sua posição no governo Lula ainda é uma incógnita.

\section{A GLOBO E AS ELEIÇÕES}

Nascida durante o regime militar, a Rede Globo de Televisão cresceu e tornou-se hegemônica graças a uma relação simbiótica com os detentores do poder". A partir do final dos anos 70, a abertura política "lenta e gradual" foi impondo novos desafios à emissora. Em 1982, com o retorno da disputa para os governos estaduais, a Globo defrontou-se com as primeiras eleições relativamente livres de sua história. A expe- 
riência foi desastrosa. Envolvida com o pleito no Estado do Rio de Janeiro, onde fica a sede da empresa, participou, ao lado de serviços de informação da ditadura, de um complô para fraudar os resultados, em uma tentativa de evitar a vitória do líder populista de esquerda Leonel Brizola - o chamado "escândalo Proconsult", em referência à empresa responsável pela totalização dos votos. Graças à apuração paralela da Rádio Jornal do Brasil, descobriu-se a fraude, e Brizola foi proclamado vencedor.

Assim, a emissora aprofundava sua opção pela manipulação política descarada, que já ficara patente na cobertura das greves operárias do ABC paulista em 1977 e 1978 - quando imagens antigas dos pátios das montadoras, repletos de veículos, eram apresentadas como novas, para demonstrar que a produção prosseguia a pleno vapor. Mas o abrandamento da censura estatal, ocorrido com a abertura, ampliava a responsabilidade da Globo por suas próprias escolhas editoriais. $\mathrm{O}$ viés manipulativo fez-se presente também em 1983 e 1984, no início da campanha por eleições diretas para presidente. Grandes manifestações populares eram ignoradas pelos telenoticiários ou, então, apresentadas como festividades desprovidas de conteúdo político. O que marcou a história das relações entre mídia e política no Brasil, porém, foi a cobertura das eleições presidenciais diretas em 1989.

Graças a uma bem-sucedida ofensiva de mídia, incluindo capas de revistas de circulação nacional, programas de televisão e o uso de horários partidários gratuitos, o governador de Alagoas, Fernando Collor de Mello, viabilizou-se como a opção das elites para impedir a vitória de um dos candidatos da esquerda (Brizola e Lula) na disputa pela Presidência. O apoio da Globo à sua candidatura ficou evidenciado desde o início, mas manifestou-se com clareza ímpar na famosa edição do último debate do segundo turno, na véspera da eleição, levada ao ar no Jornal Nacional. Os melhores momentos de Collor foram unidos aos piores de Lula, em uma manipulação grosseira, cuja lembrança volta a cada eleição como um fantasma a assombrar os jornalistas da emissora.

Da fraude na contagem dos votos à mera adulteração das informações de campanha houve um passo significativo na direção de um comportamento mais civilizado - ao menos ostensivamente - no processo eleitoral. Outros passos foram dados nas eleições posteriores. Em 1994, conforme o então ministro Rubens Ricúpero declarou em 
suas famosas confissões, o apoio à candidatura de Fernando Henrique Cardoso era dado de forma indireta, por meio da promoção do novo pacote antiinflacionário do governo, o Plano Real. E em 1998 a Rede Globo colaborou para a reeleição de FHC, eliminando a campanha de seus noticiários - em especial do Jornal Nacional, o mais importante deles -, o que ia ao encontro da estratégia oficial de esvaziamento do debate público, de negação da existência de alternativas e de transformação do pleito em um simples ritual de recondução do presidente ao cargo.

O cenário das eleições de 2002, por sua vez, não permitia sequer que se sonhasse com a reprodução de tal estratégia. Em primeiro lugar, Fernando Henrique era legalmente impedido de tentar uma nova reeleição. Na ausência de seu candidato natural - o próprio presidente-, a coalizão governista envolveu-se em uma violenta disputa interna que terminou por fraturá-la. O PFL afastou-se, após as denúncias de corrupção que destruíram as pretensões presidenciais da então governadora do Maranhão, Roseana Sarney. E o próprio PSDB ficou cindido, uma vez que o postulante preterido (o governador do Ceará, Tasso Jereissati) negou apoio ao escolhido, o ministro José Serra.

Além disso, o segundo mandato de Fernando Henrique foi marcado pela baixa popularidade. O controle inflacionário, principal conquista que tinha a apresentar, perdera boa parte de seu charme eleitoral; mazelas como baixo crescimento econômico e alto índice de desemprego ganhavam visibilidade crescente. A oposição, por sua vez, apresentou três candidatos com viabilidade eleitoral. O ex-governador e ex-ministro Ciro Gomes, do PPS, considerado bom comunicador, aliou-se ao PTB (que deixou, assim, a base do governo) e ao PDT, o que lhe garantiu alguma estrutura partidária e mais tempo de propaganda no rádio e na TV, e, mais importante ainda, obteve o apoio informal da maior parte do PFL. Já Anthony Garotinho, do PSB, possuía uma sólida base eleitoral no Rio de Janeiro, onde era governador, e penetração na população evangélica, um importante contingente de votos. Os lances políticos mais ousados, porém, vieram do PT. Principal partido da esquerda brasileira, lançou pela quarta vez a candidatura de Luiz Inácio Lula da Silva à Presidência da República, tendo adotado uma política de alianças de extremo pragmatismo. Afora o PC do B, PCB e PMN, aliados tradicionais, coligou-se com um partido de direita que também fazia oposição ao governo de Fernando Henrique, o Partido Liberal. Igualmente, consolidou o apoio de fatias im- 
portantes do PMDB e do PFL, em especial da ala comandada pelo ex-presidente José Sarney.

O candidato a vice-presidente não foi, como das vezes anteriores, um veterano militante da esquerda brasileira, mas um grande capitalista, o senador mineiro José Alencar, proprietário da maior indústria têxtil do Brasil, que se filiou ao PL especialmente para permitir a composição da chapa. A dobradinha Lula/José Alencar foi montada com o incentivo do marqueteiro Duda Mendonça: simbolizaria a união entre capital e trabalho, ao mesmo tempo que juntaria dois "vencedores", homens de origem humilde que triunfaram por seus próprios méritos, um como político, outro como empresário. A própria presença de Mendonça sinalizava as mudanças na candidatura petista. $\mathrm{O}$ marqueteiro tinha seu nome associado ao do líder da direita paulista Paulo Maluf, cuja ressurreição política, nos anos 90 , foi seu maior triunfo profissional. A repulsa a Maluf, um homem associado à ditadura e alvo de persistentes denúncias de improbidade, foi durante muito tempo uma das poucas coisas que uniam o centro e as esquerdas no Brasil. Por isso, parte da cúpula e muito da base do PT hostilizaram, de início, a participação de Mendonça na campanha ${ }^{3}$.

Os movimentos do PT em busca de alianças foram dificultados pela principal mudança no quadro institucional da eleição de 2002: a polêmica decisão do TSE que impunha a "verticalização" das coligações, isto é, a obrigatoriedade de as alianças partidárias nos estados acompanharem os acordos nacionais. Como em muitos estados os petistas eram adversários históricos de seus novos companheiros na eleição presidencial, houve certa tensão. A coligação com o PL só pôde concretizar-se graças às muitas lacunas que a decisão do TSE deixou abertas $^{4}$.

\section{A "MAIOR COBERTURA DA HISTÓRIA"}

A comparação com as eleições de 1998 deixa patente a completa transformação da postura da Rede Globo, ocorrida em 2002. Conforme argumentei em pesquisa anterior, em 1998 a emissora optou por esvaziar a disputa eleitoral, que foi praticamente ignorada por seus noticiários, em especial pelo mais importante deles, o Jornal Nacional (Miguel, 1999; 2002). Naquele ano, para a Presidência, houve apenas um turno. No período mais "quente" da campanha - as doze semanas entre a final da Copa do Mundo e a data da votação -, o Jornal Nacional 
dedicou ao todo $1 \mathrm{~h} 16 \mathrm{~min} 34 \mathrm{~s}$ à cobertura das eleições, ou 4,6\% do seu tempo total ${ }^{5}$. Em 2002, foram quatorze semanas entre o término da Copa e o primeiro turno; as eleições presidenciais ocuparam $12 \mathrm{~h} 55 \mathrm{~min} 50$ s do noticiário, isto é, $29,4 \%$ do tempo total do jornal; as eleições nos estados consumiram mais $46 \mathrm{~min} 11 \mathrm{~s}$. Ao todo, portanto, o processo eleitoral ficou com $31,2 \%$ do tempo do noticiário.

Não foi só o Jornal Nacional. Entrevistas ao vivo com os candidatos, extensas para os padrões usuais do telejornalismo, foram realizadas nos vários noticiários da emissora. Ocorreu um debate com os quatro principais candidatos logo antes do primeiro turno e outro com os dois finalistas, às vésperas do segundo, ao passo que, em 1998, não foi realizado nenhum debate televisionado com os postulantes à Presidência da República, por nenhuma das emissoras.

O Gráfico 1 ilustra outra diferença significativa. Em 1998, a escassa cobertura das eleições foi concentrada na última quinzena de campanha - na verdade, mais da metade do tempo corresponde às quatro últimas edições do Jornal Nacional. Em 2002, há uma atenção permanente ao processo eleitoral e um crescimento constante do tempo dedicado à cobertura do mesmo, que alcança quase $60 \%$ do noticiário na última quinzena. Trata-se de uma mudança com repercussão potencial importante. Em 1998, quando o Jornal Nacional finalmente se volta para o pleito, não há mais tempo, ou há muito pouco tempo, para que o debate tome conta da sociedade e os votantes refaçam suas opções.

\section{Gráfico 1}

Tempo Dedicado às Eleições no Jornal Nacional (quinzenas faltantes para o primeiro turno)

(\%)

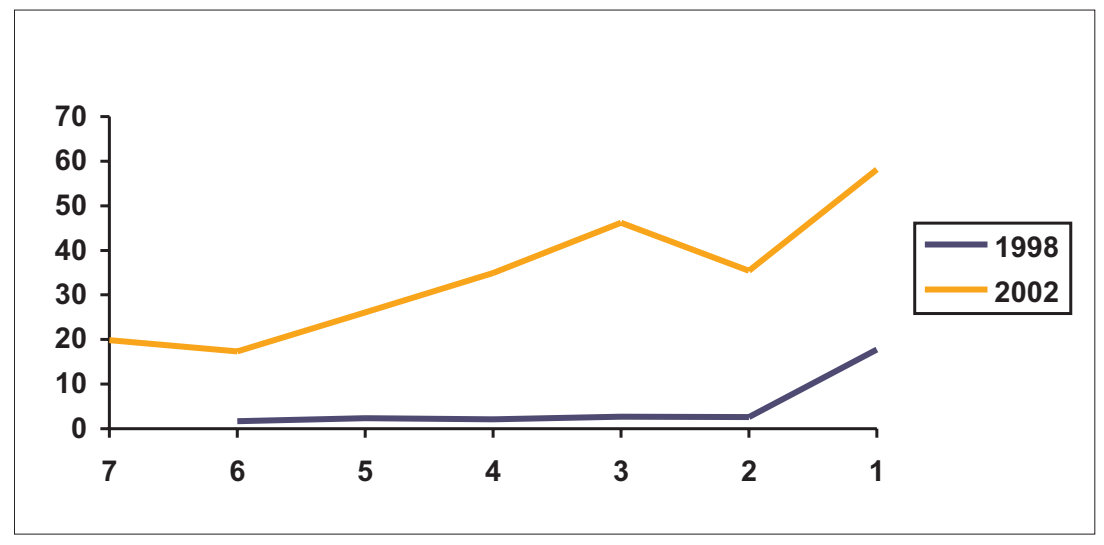


A rubrica "cobertura eleitoral" engloba vários tipos de reportagem. Em 1998, o Jornal Nacional dedicou, nas semanas estudadas, mais de meia hora para a divulgação de resultados de sondagens de intenção de voto e tempo similar para matérias de variedades (a eleitora mais velha, a eleitora mais jovem) ou de serviços (ensinando como operar a urna eletrônica, por exemplo). Para o debate eleitoral propriamente dito - declarações dos candidatos, alianças, comícios - sobraram apenas 10min24s. Em 2002, não faltaram divulgação de resultados de pesquisas e reportagens sobre serviços/variedades. Mas a presença do debate eleitoral foi elevada ao longo de todo o tempo. Outrossim, houve uma nova categoria de reportagens: séries sobre problemas brasileiros apresentadas explicitamente com o objetivo de incluí-los na agenda da campanha e extrair compromissos dos candidatos.

Não foram apenas as reportagens voltadas a pautar os candidatos: de forma geral, a Globo atribuiu a si própria a posição de "regente das eleições", o que ficou claro nas entrevistas em estúdio e, sobretudo, nos debates. O cumprimento das regras estritas determinadas pela produção era severamente garantido pelo mediador William Bonner, em nome da manutenção de um "alto nível" do qual ele era o juiz - e que exilava boa parte da discussão política ${ }^{6}$. Desejosos de evitar uma contenda com a emissora, os candidatos submeteram-se às imposições.

\section{Quadro 1}

Cobertura do Primeiro Turno das Eleições Presidenciais em 2002, no Jornal Nacional

\begin{tabular}{|l|c|c|c|c|c|c|c|c|}
\hline & $\mathbf{1}$ a $\mathbf{1 3 / 7}$ & $\mathbf{1 5}$ a $\mathbf{2 7 / 7}$ & $\begin{array}{c}\mathbf{2 9 / 7} \text { a } \\
\mathbf{1 0 / 8}\end{array}$ & $\mathbf{1 2}$ a 24/8 & $\begin{array}{c}\mathbf{2 6 / 8} \text { a } \\
\mathbf{7 / 9}\end{array}$ & $\mathbf{9}$ a 21/9 & $\begin{array}{c}\mathbf{2 3 / 9} \text { a } \\
\mathbf{5 / 1 0}\end{array}$ & Total \\
\hline Sondagens & $0: 03: 48$ & $0: 05: 55$ & $0: 10: 08$ & $0: 04: 29$ & $0: 07: 14$ & $0: 09: 30$ & $0: 12: 58$ & $0: 53: 52$ \\
Variedades/Serviço & $0: 04: 49$ & $0: 09: 54$ & $0: 09: 17$ & $0: 05: 41$ & $0: 00: 53$ & $0: 00: 21$ & $0: 25: 01$ & $0: 55: 56$ \\
Debate eleitoral & $1: 17: 37$ & $1: 07: 04$ & $1: 26: 33$ & $1: 10: 15$ & $0: 56: 19$ & $0: 40: 17$ & $1: 38: 46$ & $8: 16: 51$ \\
Problemas brasileiros & - & - & $0: 24: 42$ & $0: 53: 14$ & $0: 39: 52$ & $0: 36: 11$ & $0: 15: 12$ & $2: 49: 11$ \\
Total para eleições & $1: 26: 14$ & $1: 22: 53$ & $2: 10: 40$ & $2: 13: 39$ & $1: 44: 08$ & $1: 26: 19$ & $2: 31: 57$ & $12: 55: 50$ \\
\hline Total do JN & $\mathbf{7 : 1 3 : 4 2}$ & $\mathbf{8 : 0 4 : 2 1}$ & $\mathbf{8 : 3 4 : 3 4}$ & $\mathbf{6 : 3 9 : 1 1}$ & $\mathbf{4 : 1 1 : 3 8}$ & $\mathbf{4 : 2 1 : 0 3}$ & $\mathbf{4 : 5 2 : 5 2}$ & $\mathbf{4 3 : 5 7 : 1 4}$ \\
\hline
\end{tabular}

Como o Quadro 1 indica, a cobertura eleitoral em 2002 - ao contrário do que ocorreu em 1998 - privilegiou um enfoque efetivamente político, mostrando a movimentação dos partidos, eventos de campanha e as idéias dos candidatos. A categoria "debate eleitoral" ocupou quase $65 \%$ do tempo destinado às eleições, o que se refletiu também no es- 
paço dado à fala dos principais postulantes à Presidência da República. Em 1998, a ausência da eleição no noticiário silenciou os candidatos. Nas doze semanas estudadas do Jornal Nacional daquele ano, Fernando Henrique Cardoso teve direito a sete sound bites (trechos de discursos ou entrevistas), como candidato ou como presidente, totalizando $3 \min 3 s$ de fala. Seus adversários apareceram ainda menos: Lula ficou com seis sound bites (total de 2min40s) e Ciro Gomes com três, todos na última semana, somando $1 \mathrm{~min} 54 \mathrm{~s}$.

Já nas quatorze semanas sob análise em 2002, os candidatos estiveram muito mais presentes. Ocorreram dois ciclos de grandes entrevistas ao vivo no estúdio da emissora, um em julho e o outro em setembro; cada um dos quatro principais candidatos foi entrevistado, a cada vez, por cerca de 10min (gerando algo em torno de $7 \mathrm{~min}$ "líquidos" de discurso não-editado). Ao todo, incluindo as entrevistas, José Serra falou 37min5s; Lula, 36min16s; Ciro Gomes, 36min15s; Anthony Garotinho, 34min19s. Mesmo os dois candidatos "nanicos" da extrema-esquerda ganharam seus sound bites, é verdade que apenas episodicamente - nove inserções cada um, totalizando 1 min23s para José Maria de Almeida (PSTU) e 1 min32s para Rui Costa Pimenta (PCO) ${ }^{7}$.

Nas 84 edições do telejornal em foco, Lula e Ciro Gomes apareceram falando em 69, Serra em 70 e Garotinho em 72. A voz dos principais candidatos foi, portanto, uma presença contínua para os espectadores do Jornal Nacional.

Os números apresentados no Quadro 2 indicam, com clareza, as transformações sofridas no padrão de cobertura da Rede Globo para as duas eleições. A campanha pela Presidência em 2002 parece ganhar centralidade ainda maior nos noticiários do segundo turno, mas trata-se sobretudo de um efeito do caráter "concentrado", em poucas semanas, da disputa final. A rigor, as porcentagens são até inferiores àquelas relativas às últimas semanas antes da votação do primeiro turno. O relevante, portanto, é o contraste com o pleito de 1998. A eleição passa da quase invisibilidade para a visibilidade quase absoluta.

Como também indica o Quadro 2, a maior visibilidade das eleições presidenciais não foi um fenômeno isolado. Em 2002, no período sob análise, o telejornal dedicou $46 \mathrm{~min} 11 \mathrm{~s}$ às eleições nos estados, o que corresponde a 1,8\% do tempo total - é bem verdade que quase sempre se limitando à divulgação de pesquisas de intenção de voto. E 
Quadro 2

Presença da Disputa Eleitoral no Jornal Nacional, em 1998 e 2002

\begin{tabular}{|l|c|c|c|}
\hline & $\mathbf{1 9 9 8}$ & $\begin{array}{c}\mathbf{2 0 0 2} \\
\mathbf{( 1}^{\mathbf{o}} \text { turno) }\end{array}$ & $\begin{array}{c}\mathbf{2 0 0 2} \\
\text { (2º } \text { turno) }\end{array}$ \\
\hline Semanas sob análise & $12^{\mathrm{a}}$ & $14^{\mathrm{a}}$ & $3^{\mathrm{b}}$ \\
Edições do Jornal Nacional no período & 72 & 84 & 18 \\
Edições com reportagens sobre as eleições & $26(36,1 \%)$ & $82(97,6 \%)$ & $18(100 \%)$ \\
Tempo total do Jornal Nacional no períodoc & $27: 53: 59$ & $43: 57: 14$ & $8: 15: 13$ \\
Tempo sobre eleições presidenciais & $1: 16: 34(4,6 \%)$ & $12: 55: 50(29,4 \%)$ & $2: 58: 02(36 \%)$ \\
Tempo sobre eleições estaduais e outros te- & & & \\
$\quad$ mas de política brasileira & $0: 23: 49(1,4 \%)$ & $2: 34: 59(5,9 \%)$ & $0: 46: 46(9,4 \%)$ \\
Tempo de "debate eleitoral”d & $0: 10: 24(0,6 \%)$ & $8: 16: 51(18,8 \%)$ & $1: 50: 34(22,3 \%)$ \\
Tempo total dos sound bites dos candidatos & & & \\
à Presidência & $0: 07: 37(0,5 \%)$ & $2: 26: 50(5,6 \%)$ & $0: 36: 17(7,3 \%)$ \\
\hline
\end{tabular}

Obs.: (a) Período entre o final da Copa do Mundo e a votação do primeiro turno.

(b) Período entre as votações do primeiro e do segundo turno.

(c) Excluídas as manchetes e as chamadas ao final de cada bloco.

(d) Reportagens sobre articulações políticas dos partidos e candidatos, eventos de campanha, entrevistas dos candidatos, propostas de governo etc.

1h48min48s (4,1\% do total) foi destinada a outros temas de política brasileira, incluindo movimentação no Congresso, conflitos de terra e denúncias de corrupção. Nas doze semanas estudadas em 1998, as eleições estaduais estiveram ausentes quase que por completo, e a política brasileira foi uma categoria residual - juntas, não somaram mais do que $23 \min 49 \mathrm{~s}$ (1,4\% do total).

Embora não haja parâmetro de comparação com 1998, quando a disputa se definiu na primeira votação, cumpre observar que a cobertura do segundo turno de 2002 também ganhou enorme destaque no Jornal Nacional. Nas dezoito edições do noticiário entre 7 e 26 de outubro, a eleição presidencial recebeu cobertura por $2 \mathrm{~h} 58 \mathrm{~min} 2 \mathrm{~s}$, o equivalente a $36 \%$ do tempo do jornal. As eleições estaduais ficaram com 7,3\% do telejornal, e outros temas de política brasileira, com mais 2,2\%. Sound bites de José Serra a pareceram em todas as edições; os de Lula, em dezesseis delas. Ao todo, cada candidato falou pouco mais de $18 \mathrm{~min}$.

É possível observar de outro ângulo a mudança no perfil do Jornal $N a$ cional, apontando, nas coberturas de 1998 e de 2002, o peso relativo de quatro grandes categorias de reportagens: "esfera pública" engloba eleições, política e economia brasileiras; "internacional", política in- 
ternacional ou interna de outros países e economia mundial ou de outros países; "outras questões de interesse público", matérias sobre saúde pública, educação, direitos do consumidor, meio ambiente, segurança pública, trânsito e assemelhadas, além da previsão do tempo; e "variedades" inclui o fait-divers, isto é, notícias que se referem ao show-business, curiosidades, esportes, crimes, desastres etc. (e também anúncios de outras atrações da emissora).

Conforme se pode verificar no Gráfico 2, em relação a 1998, os telejornais de 2002 apresentam um incremento notável no espaço concedido à categoria "esfera pública", que se tornou a mais presente no noticiário, ocupando $44,9 \%$ do tempo total (contra $12,9 \%$ nas eleições anteriores); há um crescimento do noticiário internacional (de 5,9\% para $10,8 \%$ ), que no entanto continua em posição secundária em relação aos outros temas, o que parece ser um traço característico do jornalismo brasileiro; e uma notável redução da presença do fait-divers (de $56,5 \%$ para $31,2 \%)^{8}$.

\section{Gráfico 2}

Categorias de Reportagens no Jornal Nacional

(período do primeiro turno)

(\%)

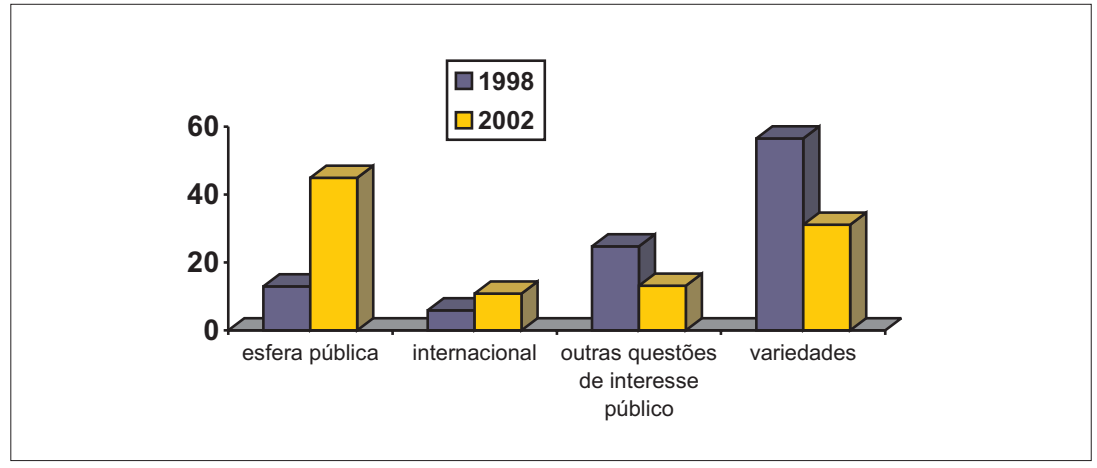

Vale observar dois aspectos dessa presença majoritária de temas da esfera pública. Em primeiro lugar, ela foi puxada pela própria centralidade das eleições no telenoticiário. Ao analisar o Jornal Nacional em 1998, era possível dizer que muitos assuntos tinham obtido um destaque maior do que a disputa eleitoral propriamente dita: a luta contra os remédios falsificados; a perseguição ao motoboy assassino; o drama do ator de televisão baleado em um assalto; e até mesmo o nascimento da filha de uma apresentadora de programas infantis. Em 2002, o qua- 
dro é diferente. O destaque absoluto foi a própria eleição presidencial. Dentre os outros assuntos que receberam atenção significativa e foram acompanhados durante várias edições do telejornal, o único que pertenceu à categoria "variedades" foi a perseguição aos assassinos do jornalista Tim Lopes, da própria Rede Globo. Ainda assim, a cobertura oscilava entre a mera reportagem policial (isto é, o puro fait-divers) e a abordagem voltada para as políticas públicas de segurança (portanto, matérias classificadas como "questões de interesse público"). Outros temas de relevo, muito presentes no noticiário, incluíam tensões na economia doméstica e mundial, o conflito árabe-israelense e a investigação sobre corrupção na prefeitura de Santo André (SP).

Em segundo lugar, as reportagens catalogadas como "esfera pública" foram contempladas com uma fatia generosa do noticiário em todo o período analisado (Gráfico 3). Em todas as semanas, foi a categoria que recebeu mais tempo no Jornal Nacional - exceto a primeira, quando as reportagens de "variedades" estiveram infladas pela vitória do Brasil na Copa do Mundo, retorno da seleção ao país e festejos ocorridos em diversas cidades.

\section{Gráfico 3}

Categorias de Reportagens no Jornal Nacional, por Semanas (primeiro turno de 2002)

(\%)

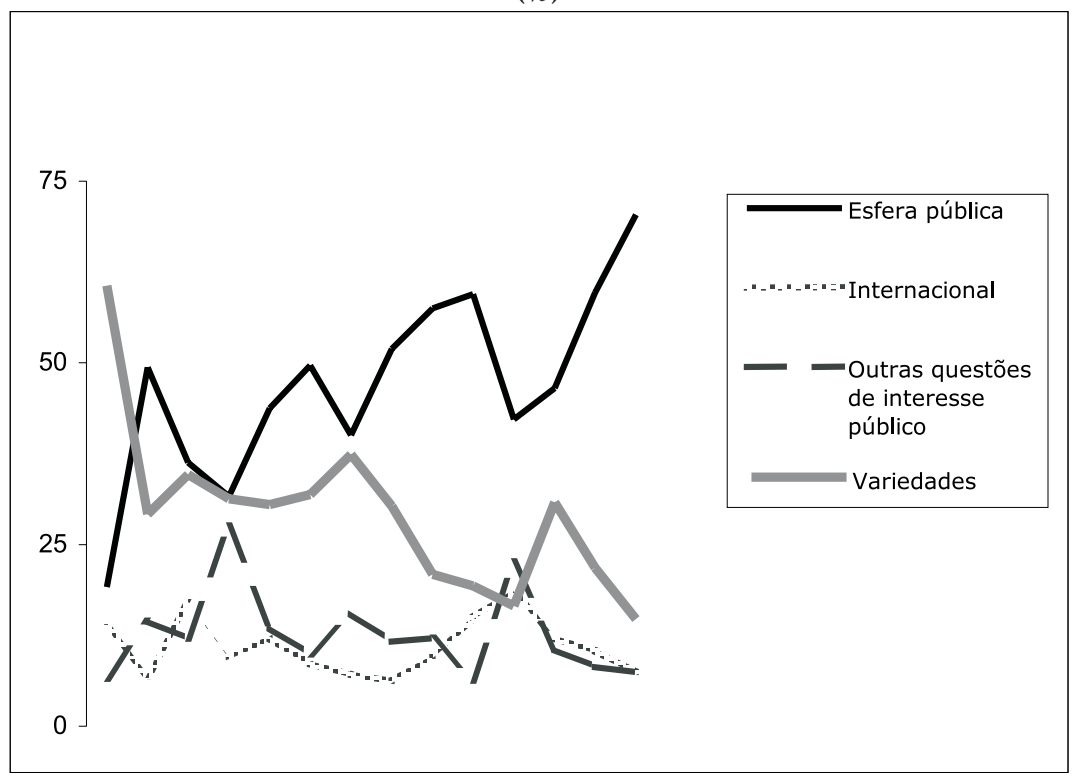


A ampliação do espaço concedido às notícias sobre a "esfera pública" foi, na verdade, maior do que a simples confrontação de porcentagens de tempo deixa entrever. Afinal, o Jornal Nacional, que se mostrou mais generoso com a cobertura das questões de política e economia, foi também um telenoticiário mais encorpado. As edições estudadas em 1998 tinham um tempo médio de 23 min 15 s; no período do primeiro turno de 2002, esta média subiu para $31 \mathrm{~min} 14 \mathrm{~s}$, ou seja, teve um acréscimo superior a um terço.

Além do tempo facultado à campanha eleitoral, outra característica marcante da cobertura desta no Jornal Nacional foi a busca quase obsessiva pela "imparcialidade", demonstrada sobretudo no equilíbrio no número de aparições e no espaço destinado a cada um dos principais candidatos. Com o objetivo expresso de evitar qualquer possibilidade de polêmica, a emissora optou por não apresentar versões editadas dos debates, nem mesmo daqueles realizados por ela (tanto no primeiro quanto no segundo turno).

Essa busca da imparcialidade foi de certa forma surpreendente. Nos meses anteriores à campanha eleitoral, a Rede Globo mostrou-se estritamente alinhada com o governo federal. Em meados de 2001, quando o presidente Fernando Henrique Cardoso rompeu com o senador Antônio Carlos Magalhães, a emissora não titubeou em abandonar um poderoso aliado de muitos anos, dono de sua repetidora na Bahia, colaborando ativamente na produção do clima de opinião que o levou à renúncia do mandato de senador (Almeida, 2002). No começo de 2002, a Rede Globo teve importante papel na implosão da candidatura presidencial da governadora Roseana Sarney, atingida por indícios de corrupção, em uma manobra que, tudo indica, partiu do candidato governista José Serra. O alinhamento com o governo parecia explicado, quando foi noticiada uma operação milionária do BNDES para salvar a Globocabo, a deficitária empresa de TV por assinatura das Organizações Globo. Mas aí a emissora decidiu fazer sua opção preferencial pela "imparcialidade", a tal ponto que, segundo alguns observadores, fez questão de marcar seu distanciamento tratando Serra, em alguns momentos, com mais rigor do que o fazia com seus adversários (Sá, 2002).

Os limites da imparcialidade do noticiário ficavam claros quando se olhava para além da agenda da emissora - e da grande imprensa em geral. Eventualmente, Serra podia ser tratado com certa dureza, mas 
denúncias graves contra o governo federal, em especial as que envolviam o ex-tesoureiro de suas campanhas, Ricardo Sérgio, sumiram da pauta. O caso Ricardo Sérgio apareceu apenas duas vezes ao longo das 84 edições analisadas, enquanto a investigação sobre denúncias de corrupção na prefeitura de Santo André, muito menos grave ou abrangente, mas que atingia o PT, mereceu onze reportagens. Ainda assim, não parece correto afirmar que houve um viés antipetista exacerbado e permanente - como escreveu, por exemplo, pouco antes da votação do primeiro turno, o jornalista Bob Fernandes (2002). Em comparação com as eleições anteriores, o noticiário da Rede Globo, de fato, avançou na direção de um tratamento mais equânime dos diversos candidatos.

Só se pode especular sobre os motivos de tal démarche - por exemplo, a necessidade de aumentar a credibilidade para sustentar a posição dominante no mercado - no momento em que, após uma alteração na Constituição, ele se abre para parcerias com conglomerados de mídia estrangeiros. Cabe ressaltar que as Organizações Globo se encontram em situação financeira difícil (Dias, 2002), o que torna, para elas, extremamente importante não só encontrar novos parceiros como também manter um relacionamento amigável com o governo, seja qual for, fonte provável de socorro nos momentos de aperto.

Foi nesse contexto, com uma Globo enfraquecida, embora longe de destroçada, que ocorreram contatos entre a cúpula petista e a direção da emissora, um pouco nos moldes daqueles que os trabalhistas britânicos estabeleceram com os tablóides conservadores, nos anos 90, visan-

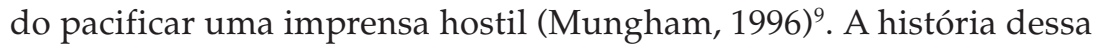
aproximação ainda há de ser contada; sua principal faceta pública, até o momento, foi a intervenção do então presidente do PT, deputado José Dirceu, desautorizando qualquer ação contra a Medida Provisória publicada pouco antes do segundo turno, que regulamentou a entrada do capital estrangeiro na mídia (e também, sem muita divulgação, eliminou entraves à concentração da propriedade no setor).

\section{O FECHAMENTO DO CAMPO DISCURSIVO}

Mais espaço para a cobertura da campanha eleitoral não é necessariamente garantia de prover a cidadania com informação de melhor qualidade (Rubim, 2002) - e tratamento equânime para os candidatos não significa neutralidade. A "imparcialidade" no noticiário sobre as elei- 
ções de 2002, no Brasil, permite observar outro - e crucial - aspecto da influência dos meios de comunicação no jogo político.

Sintetizando algumas das observações de Pierre Bourdieu sobre o funcionamento do campo político, é possível dizer que um dos papéis que ele cumpre é o de fixar o espaço do "politicamente aceitável". A exigência de comportamento "responsável" e "confiável" contribui para fechar o campo político, excluindo os grupos que não se conformam com os papéis que lhes cabem e buscam redefinir as fronteiras da própria política (Bourdieu, 1989:172). Aliás, uma das funções do intelectual crítico, na visão do sociólogo francês, é intervir de maneira "subversiva" no debate político, colocando-se contra a maré, forçando a ampliação do espaço do politicamente "dizível", questionando os consensos estabelecidos (Bourdieu, 1992: post-scriptum).

É claro que a determinação de tal espaço é fruto de lutas no interior do próprio campo político (e, nesse sentido, é possível interpretar a visão de Bourdieu como uma versão mais fraca da concepção gramsciana de hegemonia). Suas fronteiras variam de acordo com mudanças no jogo de forças. Para ilustrar, basta lembrar de como, no Brasil, a partir da fase final da ditadura militar, foi banido qualquer discurso que não aceitasse as instituições da democracia representativa; e como um novo fechamento é imposto paulatinamente, desde o governo Collor, circunscrevendo o espaço do dizível à aceitação de determinadas "regras" da economia de mercado.

A mídia cumpre um papel importante nesse processo, na medida em que enaltece antigos desviantes que se adaptam ao novo consenso sinal de seu "amadurecimento" - e relega os renitentes ao ostracismo, ignorando suas posições ou, então, folclorizando-as. Não se trata de um processo determinado conscientemente, nem que esteja isento de contradições; mas as linhas gerais são bem perceptíveis. Um estudo do tratamento dado às tendências internas do próprio PT seria significativo. Os grupos mais à esquerda foram, desde cedo, estigmatizados como "xiitas", termo com uma carga pejorativa inescapável (ao contrário de sua contrapartida, o "light" que adjetiva os petistas mais moderados). Suas posições foram, cada vez mais, julgadas irrelevantes para o debate político, em um processo que se realimentava: a menor visibilidade pública, isto é, na mídia, limitava as chances eleitorais da esquerda partidária; o baixo rendimento eleitoral minava suas po- 
sições na estrutura partidária; a menor quantidade de cargos eletivos e partidários controlados por ela justificava a ausência na mídia ${ }^{10}$.

Assim, a mídia reforça o trabalho do campo político no sentido de "domesticar" esse tipo de força, premiando as demonstrações de "moderação", "responsabilidade" e "respeitabilidade", o que contribuiu para alterar a composição de forças dentro do próprio partido. Independente do mérito das posições políticas mais extremadas, que aqui não me cabe julgar, isso concorre para estreitar o espaço do debate, isto é, para rebaixar a esfera pública.

Nas eleições de 2002, o principal instrumento de fechamento do campo discursivo - e "enquadramento" dos candidatos em um figurino estrito - foi o agravamento da crise econômica. Ao longo das duas gestões de FHC na Presidência, o país tornou-se altamente vulnerável aos movimentos do capital financeiro internacional. Com a turbulência na economia mundial provocada pelos atentados ao World Trade Center e ao Pentágono, em setembro de 2001, e em seguida pela crise de confiança na bolsa estadunidense, suscitada por sucessivos escândalos contábeis envolvendo grandes corporações, tudo isso aliado à quebra da Argentina e do Uruguai, parceiros do Mercosul, a posição do Brasil apenas piorou.

Nesse cenário, passou a ser destacada a necessidade de gerar "confiança" nos operadores do mercado financeiro. A oscilação do câmbio dominou o noticiário desde o final da Copa do Mundo até a eleição; a expressão "risco-país", medida da confiabilidade diante dos credores externos, tornou-se corrente na mídia de massa. Em especial, os principais candidatos à Presidência foram levados a manifestar seu compromisso com a continuidade de alguns dos pilares do modelo econômico vigente - e mesmo a apoiar, em uníssono, o novo acordo com o FMI, fechado no início de agosto. Tratava-se de minorar a "incerteza" que as eleições provocavam no funcionamento da economia; ou, dito de outra forma, de procurar restringir brutalmente a margem de manobra do novo governo em relação à política econômica.

Os dois inexpressivos representantes da extrema-esquerda continuaram afirmando sua oposição, mas possuíam peso eleitoral tão ínfimo que não constituíam ameaça. Foram alijados do debate, com o aval do TSE, que decidiu que as regras de tratamento equânime só valiam para os candidatos das coligações que contassem com presença no 
Congresso Nacional. Assim, José Maria de Almeida (PSTU) e Rui Costa Pimenta (PCO) puderam ser ignorados pelo noticiário e não foram convidados para os debates na televisão ${ }^{11}$.

Duas estratégias principais de fechamento do campo discursivo podem ser identificadas ${ }^{12}$. A mais evidente consistia na obtenção de promessas por parte dos candidatos. Nas entrevistas e nos debates, o âncora do Jornal Nacional, William Bonner, cobrava de todos (em especial dos três oposicionistas) a "manutenção dos contratos", o pagamento das dívidas externa e interna e o compromisso com o ajuste fiscal. Da forma como o diálogo era posto (e uma vez que nenhum candidato se dispunha a contestá-lo), parecia que Bonner exigia algo tão evidente quanto a honestidade no trato com o dinheiro público, isto é, algo que não permitisse discordâncias no campo da política e que marcasse o desviante como portador de um déficit moral.

A outra estratégia se dava no agendamento e no enquadramento dos temas. De um lado, pelo silenciamento sobre certas questões. A negociação com os Estados Unidos para a formação da ALCA, considerada crucial pela totalidade da elite política e econômica brasileira, pouco apareceu nos noticiários; quando surgia, era completamente dissociada das eleições - o que contou com a colaboração dos quatro principais candidatos, que preferiam não tocar em assunto tão espinhoso, tanto pela dificuldade de compreensão pelo eleitor comum quanto pelos interesses que afeta. Os candidatos da extrema-esquerda apresentavam a ALCA como parte de uma estratégia imperialista, porém, mais uma vez, não tiveram força para incluir a questão na agenda.

De outro lado, algumas questões mostravam alta visibilidade. Em 2002, a economia brasileira ocupou 9,4\% do Jornal Nacional - um aumento perceptível em relação aos 6,9\% de 1998. Mais importante do que o tempo, contudo, era a atenção permanente às "sensibilidades" do mercado. A oscilação da bolsa e do câmbio era acompanhada mais detalhadamente do que o habitual, mas a novidade era a inclusão constante do "risco-país" e seus assemelhados (índices de diversas consultorias financeiras estrangeiras, notas concedidas a papéis brasileiros etc. $)^{13}$.

A centralidade absoluta dessas questões ficava ainda mais evidente na mídia impressa, destinada a um público mais sofisticado. À guisa 
de ilustração, o Quadro 3 mostra a distribuição por temas da principal manchete diária do jornal Folha de S. Paulo, nos meses de julho a outubro, em 2000 (ano de eleições municipais), 2001 (ano não eleitoral) e 2002 (ano de eleições gerais); qualquer outro grande jornal apresentaria números similares. É notório o crescimento da importância concedida ao noticiário econômico e o esvaziamento da política em sentido estrito. Isso fica ainda mais claro quando se acrescenta que, dentre as 24 manchetes principais de 2002 que tratavam de política, 22 focavam o resultado de pesquisas pré-eleitorais (ou os resultados do primeiro turno).

\section{Quadro 3}

Manchete Principal da Folha de S. Paulo

de Julho a Outubro de 2000, 2001, 2002

(\%)

\begin{tabular}{|l|c|c|c|}
\hline & $\mathbf{2 0 0 0}^{\mathbf{a}}$ & $\mathbf{2 0 0 1}$ & $\mathbf{2 0 0 2}^{\mathbf{b}}$ \\
\hline Economia & 22,3 & 35,7 & 57,1 \\
Política & 49,6 & 17,1 & 20,2 \\
Economia $_{\text {política }}{ }^{\mathrm{c}}$ & 9,1 & 0,8 & 8,4 \\
Internacional & 11,6 & 36,6 & 8,4 \\
Outros & 7,4 & 9,8 & 5,9 \\
\hline & $n=121$ & $n=123$ & $n=119$ \\
\hline
\end{tabular}

Obs.: Para o ano de 2002 foi usada, via de regra, a "Edição Brasília"; para 2000 e 2001, a "Edição São Paulo".

(a) Até o dia 29 de outubro (data do segundo turno).

(b) Até o dia 27 de outubro (data do segundo turno).

(c) A manchete principal tratava expressamente da confluência entre decisões políticas e situações econômicas.

Por outro lado, a cotação do dólar diante do real foi assunto da principal manchete da Folha de S. Paulo por 27 vezes nos quatro meses analisados em 2002. Em 2001, o câmbio mereceu quatro manchetes principais e em 2000, apenas uma. Finalmente, em 2002, por 39 vezes a Folha destacou em sua capa - em manchete ou não-o impacto que a escolha de tal ou qual candidato tinha naqueles indicadores econômicos que ela privilegiava (câmbio, bolsa, "risco-país"). O risco de Ciro Gomes ultrapassar José Serra alarmava o "mercado" $(6 / 7,18 / 7)$, a reação de Serra o acalmava $(17 / 8,14 / 9)$, a hipótese da vitória de Lula no primeiro turno voltava a assustá-lo $(17 / 9,19 / 9,20 / 9,24 / 9,28 / 9,29 / 9)$, mas a "moderação" do candidato do PT enfim o apaziguava (25/10, 26/10). 
Não se trata de negar a gravidade da crise econômica que se "impunha" como tema dominante. No entanto, uma vez que se reconhece que o jornalismo não é mero reflexo da realidade, mas também um de seus elementos constitutivos, fica claro que o recorte que se fazia do momento, iluminando certos aspectos em detrimento de outros, beneficiava uma interpretação do mundo social e de suas alternativas. Em 2002, a oposição - em especial seu candidato mais importante, Lula - optou por não remar contra a maré, adaptando-se ao modelo discursivo dominante.

\section{CONCLUSÕES}

Parece claro que a mídia cumpriu um papel saliente no processo de fechamento do espaço do dizível. Ao contrário de algumas análises feitas no momento, creio que, independente das intenções de seus emissores, a vinculação estrita que a imprensa fez entre a eleição e a crise econômica, com a subida dos candidatos de oposição nas pesquisas correspondendo à desvalorização do real e à queda nas bolsas, contribuiu menos para alavancar o candidato do governo, José Serra, e mais para extrair dos candidatos da oposição compromissos cada vez mais abrangentes com a continuidade da política econômica liberal. À incerteza, própria do jogo eleitoral e mesmo da democracia (Przeworski, 1984), opôs-se, com êxito, a necessidade de "segurança" para os investidores externos.

A Rede Globo de Televisão deu, em 2002, um passo significativo na transformação de seu comportamento em períodos eleitorais. É possível apenas especular se as razões para tanto são de natureza jornalística, empresarial ou política - ou, provavelmente, uma combinação das três. Não se pode negar que ocorreram avanços importantes na direção da imparcialidade em relação aos candidatos relevantes e uma notável ampliação da massa de informações colocada à disposição do público. Sem pretender reduzir o alcance de tais acontecimentos, cumpre observar que a abertura da Globo à disputa eleitoral foi concomitante à diminuição do espectro de alternativas efetivamente apresentadas ao eleitorado.

Além disso, a campanha de 2002 revelou com clareza que a opção por um candidato é apenas a forma mais grosseira que os meios de comunicação possuem para influenciar o processo eleitoral. Na medida em que toda notícia pressupõe uma seleção e uma hierarquização da in- 
formação, os veículos da mídia nunca podem atingir a neutralidade que por vezes postulam e, necessariamente, contribuem para a construção de uma determinada representação do mundo social. A que a Rede Globo privilegiou vetava, de antemão, qualquer discussão sobre a alteração do modelo macroeconômico.

Como o breve excurso sobre a Folha de S. Paulo sinalizou, essa não foi uma característica exclusiva da Globo, mas algo comum a toda a grande imprensa. O público viu-se, portanto, diante de uma leitura uniforme da realidade, fruto do baixo pluralismo vigente na mídia brasileira. E os candidatos competitivos, conscientes do poder dos meios de comunicação, adaptaram-se a essa leitura, estreitando o espaço do debate político.

(Recebido para publicação em maio de 2003)

(Versão definitiva em setembro de 2003)

\section{NOTAS}

1. Na primeira semana do novo governo, o ministro das Comunicações, Miro Teixeira, anunciou uma mudança concreta, pequena mas significativa: a divulgação pública dos nomes dos controladores das empresas de radiodifusão. Após oito meses de mandato, a promessa ainda não havia sido cumprida.

2. Para a trajetória da Rede Globo, com ênfase no papel político por ela desempenhado da "abertura" do regime militar até as eleições de 1998, ver Miguel (2002, cap. 1). Sobre sua relação com o governo militar, sobretudo nos anos 60, ver Herz (1987).

3. Não foi o maior sapo que tiveram que engolir. Às vésperas do segundo turno, Maluf anunciou seu apoio a Lula (e, em especial, ao candidato do PT ao governo de São Paulo, José Genoíno). A declaração do veterano líder direitista foi a mais emblemática da amplitude das alianças que os petistas estiveram dispostos a aceitar.

4. Mas o apoio formal do PFL a Ciro Gomes, que multiplicaria o tempo de televisão do candidato do PPS, foi liquidado com a verticalização das coligações. Nesse e em outros episódios, foram freqüentes as denúncias de que o TSE favorecia José Serra, o que se explicaria pela íntima relação de amizade entre o candidato do PSDB e o presidente do Tribunal (e ex-ministro de Fernando Henrique Cardoso), Nelson Jobim.

5. Para efeito da totalização do tempo do telejornal, foram desconsideradas as chamadas iniciais e as chamadas ao final de cada bloco.

6. O medo de "baixaria" na campanha eleitoral limita a expressão do conflito político, que idealmente tomaria a forma de um concurso de propostas para o bem público. 


\section{Luis Felipe Miguel}

No entanto, denúncias e acusações entre os candidatos podem agregar mais informação relevante para a decisão do voto por parte do eleitor do que os mais bonitos programas de governo.

7. Observe-se que, ainda assim, José Maria e Rui Pimenta obtiveram mais inserções do que Fernando Henrique, Lula ou Ciro Gomes em 1998.

8. Segundo dados obtidos pouco depois do 11 de setembro de 2001, os atentados terroristas em Nova Iorque e Washington fizeram com que os telejornais dos Estados Unidos invertessem a tendência de priorizar as variedades e passassem a dedicar mais espaço às "hard newws" (Lo Prete, 2001). No entanto, os dados não permitem afirmar se essa tendência se sustentou além do curto prazo, nem qual o impacto em outros países.

9. Baseio-me em comunicações pessoais de assessores da direção do Partido dos Trabalhadores.

10. Uma reportagem de capa da revista Veja, publicada às vésperas do segundo turno em 2002, é exemplar: são sete páginas ridicularizando as "medidas anacrônicas" propostas pela esquerda do PT e advertindo Lula, cuja eleição já era dada como certa, da necessidade de banir os radicais de seu governo (Graieb, 2002).

11. A decisão do TSE justificava-se diante da experiência das eleições anteriores, que foram "poluídas" pela grande quantidade de candidatos, muitos deles meros oportunistas. Em 1998, concorreram doze candidatos, dos quais três concentraram mais de $95 \%$ dos votos válidos; oito ficaram com menos de $0,4 \%$ dos votos cada.

12. O termo "estratégia" não pretende indicar nenhum tipo de intenção "maquiavélica" por parte dos agentes.

13. É possível especular que muito poucos, entre os estimados cinqüenta milhões de espectadores do Jornal Nacional, seriam capazes de preencher a expressão "risco-país" com qualquer conteúdo razoável (a despeito de tentativas esparsas, e na verdade um tanto preguiçosas, de explicação no próprio telejornal). Mas a associação entre determinadas políticas e o aumento do "risco" parecia bem clara.

\section{REFERÊNCIAS BIBLIOGRÁFICAS}

ALMEIDA, Jorge. (2002), Mídia, Estado e Sociedade Civil na Renúncia de ACM. Trabalho apresentado no 11을 Encontro da Compós. Rio de Janeiro, 4-7 de julho.

BOURDIEU, Pierre. (1989), “A Representação Política. Elementos para uma Teoria do Campo Político", in O Poder Simbólico. Rio de Janeiro, Bertrand Brasil/Difel. . (1992), Les Règles de l'Art: Genèse et Structure du Champ Littéraire. Paris, Seuil.

DIAS, Maurício. (2002), “Vênus Endividada”. Carta Capital, no 214, pp. 26-31.

FERNANDES, Bob. (2002), “E a Máquina Avança”. Carta Capital, n-o207, pp. 24-29. 
GRAIEB, Carlos. (2002), "Vai Ser Preciso Segurar". Veja, 23 de outubro, pp. 38-44.

HERZ, Daniel. (1987), A História Secreta da Rede Globo. Porto Alegre, Tchê!.

LO PRETE, Renata. (2001), "Terror Muda Pauta do Telejornalismo Americano". Folha de S. Paulo, 2 de dezembro, p. A-25.

MIGUEL, Luis Felipe. (1999), “Mídia e Eleições: A Campanha de 1998 na Rede Globo”. Dados, vol. 42, no 2, pp. 253-276.

_.. (2002), Política e Mídia no Brasil: Episódios da História Recente. Brasília, Plano.

MUNGHAM, Geoff. (1996), “A Batalha pelo Controle da Agenda: A Mídia, os Políticos e o Processo Eleitoral na Grã-Bretanha". Comunicação \& Política, vol. III, nํㅡ2, Nova Série, pp. 30-45.

PRZEWORSKI, Adam. (1984), “Ama a Incerteza e Serás Democrático". Novos Estudos CEBRAP, no 9, pp. 36-46.

RUBIM, Antonio Albino Canelas. (2002), "Mídia e Visibilidades". Correio Braziliense, Caderno "Pensar", 6 de outubro, pp. 4-5.

SÁ, Nelson de. (2002), “Desastroso”. Folha de S. Paulo, 11 de julho, p. A-9.

\section{GLOSSÁRIO}

ALCA - Área de Livre Comércio das Américas

BNDES - Banco Nacional de Desenvolvimento Econômico e Social

FMI - Fundo Monetário Internacional

PCB - Partido Comunista Brasileiro

PC do B - Partido Comunista do Brasil

PCO - Partido da Causa Operária

PDT - Partido Democrático Trabalhista

PFL - Partido da Frente Liberal

PL - Partido Liberal

PMDB - Partido do Movimento Democrático Brasileiro

PMN - Partido da Mobilização Nacional

PPS - Partido Popular Socialista

PSB - Partido Socialista Brasileiro

PSDB - Partido da Social Democracia Brasileira

PSTU - Partido Socialista dos Trabalhadores Unificado

PT - Partido dos Trabalhadores

PTB - Partido Trabalhista Brasileiro

TSE - Tribunal Superior Eleitoral 


\section{ABSTRACT}

The Visible Election: The Globo Television Network Discovers Politics in 2002

The Globo television network conducted extensive coverage of the 2002 election process in Brazil. During the 17 weeks between the end of the Football World Cup and the second round of the Brazilian elections, the Presidential race occupied approximately one third of air time on the network's main nationwide news program, Jornal Nacional. This was a marked difference in comparison to coverage of the 1998 elections, which were virtually absent from the Globo news broadcasts. The network also pursued a policy of clear impartiality towards the four main Presidential candidates, in stark contrast to its almost militant involvement in previous races. This article seeks to demonstrate that the influence of the Globo network on the election process in 2002 occurred primarily through its collaboration in closing off the discursive field, demanding that candidates assume an increasingly deep commitment to the continuation of prevailing macroeconomic policies.

Key words: communications media; elections; Brazilian politics

\section{RÉSUMÉ \\ L'Élection Visible: La Châ̂ne de Télévision Globo Découvre la Politique en 2002}

2002 est l'année où la chaîne Globo a effectué un gros travail de reportage sur le processus électoral brésilien. Pendant les dix-sept semaines allant de la fin de la Coupe du Monde de football jusqu'au second tour du scrutin, l'élection présidentielle a occupé un tiers environ de toute la durée du Jornal Nacional sa plus importante émission d'informations. La différence est remarquable par rapport aux élections de 1998 pratiquement délaissée par la chaîne. On y repère aussi une impartialité manifeste dans la façon de présenter les quatre candidats à la présidence, à l'opposé de l'engagement presque militant de Globo aux élections précédentes. On cherche ici à montrer que l'influence de cette chaîne sur le processus électoral s'est montrée surtout dans sa façon de clore le champ $d u$ discours, de par son exigence auprès des candidats d'un engagement toujours plus ferme sur la continuité des politiques macroéconomiques.

Mots-clés: moyens de communication; élections; politique brésilienne 